DOI: $10.1515 / \mathrm{rrlm}-2016-0044$

\title{
IL-6 gene polymorphisms and sepsis in ICU adult romanian patients: a prospective study
}

\author{
Polimorfismele genei IL-6 și sepsisul la pacienți români \\ dintr-un serviciu de terapie intensivă - studiu prospectiv
}

\author{
Anca Meda Georgescu', Claudia Bănescu'²*, Iudita Badea ${ }^{3}$, Valeriu Moldovan ${ }^{4}$, \\ Adina Huțanu ${ }^{5}$, Septimiu Voidăzan ${ }^{6}$, Minodora Dobreanu ${ }^{5}$, Leonard Azamfirei ${ }^{3}$ \\ IInfectious Diseases Clinic, University of Medicine and Pharmacy Tirgu Mureș, Romania, \\ ${ }^{2}$ Department of Genetics, University of Medicine and Pharmacy, Tirgu Mureș, Romania, \\ ${ }^{3}$ Anesthesiology and Intensive Care Clinic, University of Medicine and Pharmacy Tîrgu Mureș, \\ Romania, \\ ${ }^{4}$ Genetics Laboratory, Center for Advanced Medical and Pharmaceutical Research, University of \\ Medicine and Pharmacy Tîrgu Mureș, Romania, \\ ${ }^{5}$ Immunology Laboratory, Center for Advanced Medical and Pharmaceutical Research, University of \\ Medicine and Pharmacy Tîrgu Mureș, Romania \\ ${ }^{6}$ Department of Epidemiology, University of Medicine and Pharmacy Tîrgu Mureș, Romania
}

\begin{abstract}
Objectives: The goal of the study was to investigate the correlations between the interleukin-6 IL-6 -174 G/C and IL-6 -572 G/C gene polymorphisms and sepsis risk and severity in adult ICU patients.

Materials and Methods: We prospectively assessed 107 septic patients and divided them into two subgroups: organ dysfunction-free sepsis subgroup $S(n=60)$ and septic shock subgroup $S S(n=47)$. A control group of 96 healthy individuals was included. Both patients and controls underwent IL-6-174 G/C and $-572 \mathrm{G} / \mathrm{C}$ genotyping and circulating IL-6 in the study group which were measured from samples taken in the first day of sepsis diagnosis.

Results: No differences in the genotype frequencies of the two polymorphisms between study and control groups were identified. The GC genotype and C allele of IL-6 -572 G/C gene polymorphism was statistically significant more frequent in the organ dysfunction-free subgroup ( $p=0.01, p=0.004$ respectively). No statistically significant differences for the IL-6-174 G/C gene polymorphism were found between the two sepsis subgroups. Circulating IL-6 levels were significantly higher in the septic shock subgroup and among patients with GG genotypes of both studied polymorphisms.

Conclusion: We underline the possible role of IL-6 -572 G/C as a marker of severe evolution. There is no evidence of a direct role of IL-6 -174 G/C gene polymorphism in sepsis risk and outcome. Il-6 levels are correlated with sepsis severity but not with variant genotype of investigated IL-6 gene polymorphisms.
\end{abstract}

Keywords: IL-6, sepsis, single nucleotid polymorphism.

* Corresponding author: Claudia Bănescu, Department of Genetics, University of Medicine and Pharmacy, Gh. Marinescu 38, Tg Mureș, Romania, e-mail: claudia.banescu@rrml.ro 


\section{Rezumat}

Obiectivul studiului a fost acela de a analiza existența unor corelații între polimorfismele genei interleukinei 6 IL-6 -174 G/C și IL-6 -572 G/C și riscul de sepsis și de mortalitate la pacienții internați într-un serviciu de terapie intensivă.

Material și metodă: am evaluat prospectiv 107 pacienți septici împărțiți în 2 subgrupe: subgrupul cu sepsis dar färă disfuncție de organ ( $n=60)$ și subgrupul (SS) cu șoc septic $(n=47)$. Am inclus un lot de control format din 96 de persoane sănătoase. Ambelor subgrupe de pacienți și grupului de control li s-a realizat genotiparea pentru IL-6 -174 G/C şi -572 G/C și li s-a determinat nivelul circulant de IL-6 din probe luate în ziua diagnosticării sepsisului. Rezultate: $N u$ s-au identificat diferențe între frecvența genotipurilor celor două polimorfisme între grupul de studiu și cel de control. Genotipul GC si alela C pentru polimorfismul IL-6 -572 G/C au fost mai frecvente in subgrupul färă disfuncție de organ ( $p=0.01$, respectiv $p=0.004)$. Nu au existat diferențe pentru polimorfismul IL-6 $-174 \mathrm{G} / \mathrm{C}$ intre cele două subgrupuri de sepsis. Nivelul circulant al IL-6 a fost semnificativ mai crescut în subgrupul cu șoc septic și la pacienții cu genotip $G G$, la ambele polimorfisme studiate.

Concluzii: subliniem posibilul rol al IL-6 572 G/C ca marker al evoluției severe. Nu s-a evidențiat rolul polimorfismului IL-6-174 G/C asupra riscului de sepsis și a evoluției. Nivelul de IL-6 este corelat cu severitatea sepsisului dar nu si cu genotipul variant al polimorfismelor IL-6 investigate.

Cuvinte cheie: IL-6, sepsis, polimorfism mononucleotidic.

Received: 09 $9^{\text {th }}$ November 2016; Accepted: 11 th December 2016; Published: $29^{\text {th }}$ December 2016

\section{Introduction}

Despite efforts in the last decade to improve its diagnosis and treatment, sepsis represents a major health problem, with a mortality that still remains high (20-50\%) (1).

The concept of Early Goal Directed Therapy (EGDT) in sepsis, which indicates treatment initiation within 6 hours of the patient's presentation to the emergency department may contribute to a significant reduction in mortality (2,3). Effective sepsis management is, nevertheless, based on early diagnosis and rapid identification of high risk patients and severity.

The concept of organ dysfunction employed in the definition of sepsis refers to a complex alteration of biological processes occurring at cellular and metabolic levels, often without a clear-cut clinical differentiation between sepsis as a general symptom and septic shock as a sepsis subcategory (4). For this reason the contribution of biomarkers with sufficient sensitivity and specificity to sepsis diagnosis, could become crucial (5).
The interaction between pathogenassociated molecular patterns (PAMPs) and the innate immune system macrophages by pattern recognition receptors (PRRS) represents one of the cellular mechanisms of sepsis occurrence. The balance between consecutively-released proinflammatory and anti-inflammatory mediators is responsible for its clinical status.

Interleukin-6 (IL-6) is encoded by a gene located to chromosome $7 \mathrm{p} 2$ region, is a cytokine with key initial proinflammatory role in the systemic inflammatory response to infectious injuries. Several studies demonstrated that IL-6 circulating levels correlate with sepsis severity and mortality rates $(6,7)$.

It has been demonstrated that certain single nucleotide polymorphisms (SNPs) in cytokines genes are associated with the risk of sepsis occurrence and its outcome (8). Recent studies have reinforced the idea of a possible genetic basis for the selection of patients with favorable potential response to personalized therapies, with a growing interest in identification of a sepsis-associated genetic predisposition (9). 
The most studied polymorphism of IL- 6 is represented by the transition of guanine $(\mathrm{G})$ to cytosine (C), namely $\mathrm{G} / \mathrm{C}$, at the -174 promoter region. In vivo demonstration of the role of $\mathrm{G}$ allele, with consequences in increasing the inflammatory response mediated by elevated cytokines circulating levels, underlined the possible involvement of variations within the regulatory part of the IL-6 gene in sepsis incidence and outcome $(10,11)$. Results in the literature are still inconclusive, some authors associating this SNP with an increased sepsis risk $(10,12,13)$, while others invalidating such associations $(14,15)$ or pointing out to its relevance in combination with other gene polymorphisms (16).

The role of $\mathrm{G} / \mathrm{C}$ transition at the -572 promoter region of IL-6 is subject to only a few studies on sepsis risk and outcome. These studies suggest a predisposition to systemic infections in patients with GG genotype for IL-6 -572G/C SNP with chronic renal diseases and trauma in certain populations $(17,18)$.

The objectives of this study were to investigate the role of IL-6 gene polymorphisms in sepsis susceptibility, severity and outcome, as well as in evaluating their association with its plasma levels.

\section{Materials}

\section{Patients and controls}

A prospective cohort study was carried out for 10 months, from September 2015 to July 2016, in the Anesthesiology and Intensive Care Clinic of the Emergency Clinical County Hospital from Tirgu Mures, Romania. The study protocol was approved by the Ethics Committees of the participating Hospital (no. 123/2015) and of the University of Medicine and Pharmacy of Tirgu Mures (no. 22462/2015). A written informed consent was signed by the patients or their first- degree relatives and the consent was archived.

Patients were enrolled according to the following inclusion criteria: Caucasian origin, age over 18 years, and sepsis (presumed/ confirmed infection accompanied by at least two of the following systemic infection manifestations: fever $>38^{\circ} \mathrm{C}$ or hypothermia $<36^{\circ} \mathrm{C}$, tachycardia $>90 / \mathrm{min}$, tachypnea $>20$ / min, leukocytosis $>12,000 \mathrm{~mm}^{3}$, leucopenia $<4,000 \mathrm{~mm}^{3}$ or $>10 \%$ immature forms).

Septic shock was considered in patients who also associated hypotension (systolic blood pressure $<90 \mathrm{~mm} \mathrm{Hg}$ or mean arterial pressure $<70 \mathrm{~mm} \mathrm{Hg}$ ) refractory to adequate volume resuscitation (19). 96 healthy unrelated individuals (44 males, 52 females) sex and age-group matched, without known infections in the previous 18 months, were included in the control group. Criteria for exclusion from the study were represented by: HIV infection, known malignancies, and autoimmune diseases requiring immunosuppressive drugs. They were applied to both patient cohort and the control group.

\section{Study design}

Patients were enrolled in the study group within the first 24 hours of sepsis onset, all cases being admitted to the intensive care unit (ICU) from medical or surgical services. The collected data were recorded in a case report form and comprised: clinical data, including the condition requiring admission (i.e. medical or emergency/elective surgical condition), primary situs of infection; severity score upon enrollment in the study (Acute Physiology and Chronic Health Evaluation - APACHE II, Simplified Acute Physiology Score - SAPS II and Sequential Organ Failure Assessment SOFA), number of hospitalization days in the ICU, days of vasoactive therapy and mechanical ventilation, date of death in case of fatal outcome; anthropometric, clinical, biological 
(haematological, biochemical), radiological and microbiological data were also recorded for each patient (outside the scope of the current study).

\section{Methods}

Blood samples were obtained by cubital venous puncture from each patient who met the inclusion criteria within the first 24 hours following the sepsis diagnosis, between 8 and 9 AM; one sample was collected in ethylenediaminotetraacetic acid (EDTA) coated tubes and centrifuged (1000 X g, 10 $\mathrm{min})$; the obtained plasma was apportioned into small aliquots and stored at $-80^{\circ} \mathrm{C}$ until it was analyzed. Another blood sample was drawn for deoxyribonucleic acid (DNA) isolation.

\section{Genotyping analysis}

Rapid isolation of ultra-pure DNA from fresh whole blood samples collected from patients and controls enrolled in the study was performed using the Quick-gDNA MiniPrep kit. For the genotyping of IL-6 single nucleotide gene polymorphisms (SNPs), we used polymerase chain reaction (PCR) methods, namely the restriction fragment length polymorphism (PCRRFLP) assay for the investigation of IL-6 -572 G/C (rs 1800796) SNP (20) and the amplificationrefractory mutation system PCR (ARMS-PCR) method for IL-6 -174 G/C (rs1800795), as previously described (21).

\section{IL-6 plasma levels determination}

To measure the level of circulating IL- 6 cytokine in our samples we used the Human premixed magnetic screening assay (R\&D Systems, Minneapolis, USA), and a multiplex technique based on xMAP technology (Luminex, Austin TX USA), which allows the detection multiple cytokines in a small sample volume. Measurements were performed according to the manufacturer's instructions.
Analyte-specific antibodies are pre-coated on internally-dyed magnetic beads. After addition of samples and incubation, the analytes of interest will bound to the specific antibodies on the magnetic particles. In a second step, specific biotinylated detection antibodies are added, forming antigen-antibody sandwich complexes, revealed by PE-streptavidin addition. The magnetic beads coupled with immune complexes will be read on a dual laser flow-based Luminex 200 (Luminex Corporation, Austin, USA) detection analyzer, one laser interrogating the type of magnetic bead, the other quantifying the concentration of each analyte by measuring the PE-streptavidin signal. The IL-6 sensitivity for the multi-analyte kit used was $1.7 \mathrm{pg} / \mathrm{mL}$.

\section{Statistical Analysis}

Statistical analysis was performed using the Statistical Package for Social Sciences (SPSS, version 20, Chicago, IL, USA) software. Data were considered as nominal or quantitative variables. Nominal variables were characterized using frequencies. Quantitative variables were tested for normality of distribution using the Kolmogorov-Smirnov test and were characterized by median and percentiles (25$75 \%$ ) or by mean and standard deviation (SD), when appropriate. Quantitative variables were compared using $\mathrm{t}$ test, Mann-Whitney test or Kruskal-Wallis test, when appropriate. In order to assess the associations between genotype distribution and other categorical variables, we used contingency tables and the chi-square test. We calculated the OR (odds ratio) to demonstrate the probability or susceptibility to sepsis according to the given polymorphisms. Deviations of allelic frequencies from HardyWeinberg equilibrium were calculated using a Chi-square test. Each polymorphism of interest was analyzed as a possible predictor for sepsis using simple binary logistic regression. We interpreted all tests against a $\mathrm{p}=0.05$ significance 
threshold and statistical significance was considered for $\mathrm{p}$-values below the significance threshold.

\section{Results}

\section{Characteristics of the patients}

A total number of 107 patients with sepsis were enrolled in the study. There was no statistically significant difference between the septic patients and controls regarding age (mean $54.1 \pm 15.5$ years vs $56.8 \pm 15.4$ years, $\mathrm{p}=0.34)$ and gender $(45.8 \%$ vs $53.3 \%$ male patients, $p=0.29$ ). Patients in the study group were divided into two subgroups based on the above-mentioned inclusion criteria: 60 patients $(56,07 \%)$ in the organ dysfunctionfree sepsis subgroup (S), and 47 patients $(43.92 \%)$ in the septic shock subgroup (SS). For further analysis, patients were subsequently sub-divided into: deceased $(\mathrm{n}=$ 76) and survivors $(n=31)$. The main baseline demographic and clinical characteristics are shown in Table 1.

Table 1. Demographic and clinical baseline characteristics of septic patients

\begin{tabular}{lccc}
\hline Patient characteristics & $\begin{array}{l}\text { Septic } \\
\text { patients }\end{array}$ & $\begin{array}{l}\text { Septic } \\
\text { shock } \\
\text { patients }\end{array}$ & \\
\cline { 2 - 4 } & \multicolumn{1}{c}{$\begin{array}{c}\mathrm{S} \\
(\mathrm{n}=60)\end{array}$} & $\begin{array}{c}\mathrm{SS} \\
(\mathrm{n}=47)\end{array}$ & $p$ \\
\hline Age (years), mean \pm SD & $60.8 \pm 15.7$ & $68.3 \pm 14.3$ & $0.01^{*}$ \\
\hline Male, $\mathrm{n}(\%)$ & $34(56.6 \%)$ & $23(48.9 \%)$ & $0.46^{* *}$ \\
\hline Primary site of infection & \multicolumn{3}{l}{} \\
\hline Abdominal, n (\%) & $5(8.3 \%)$ & $13(27.6)$ & $0.01^{* *}$ \\
\hline Cerebral, n (\%) & $3(5.0 \%)$ & $1(2.1)$ & $0.79^{* *}$ \\
\hline Cutaneous and soft tissue, n (\%) & $5(8.3 \%)$ & $5(10.6)$ & $0.94^{* *}$ \\
\hline Pulmonary, n (\%) & $4676.6 \%)$ & $25(53.2)$ & $0.01^{* *}$ \\
\hline Urinary, n (\%) & $1(1.6)$ & $3(6.3)$ & $0.44^{* *}$ \\
\hline Length of ICU stay (days), median (range) & $12(2-52)$ & $5.5(1-29)^{*}$ & $0.0012^{* * *}$ \\
\hline $\begin{array}{l}\text { Duration of mechanical ventilation (days), median } \\
\text { (range) }\end{array}$ & $6(0-41)$ & $3(1-29)^{*}$ & $0.0303^{* * *}$ \\
\hline $\begin{array}{l}\text { Duration of vasoactive therapy (days), median } \\
\text { (range) }\end{array}$ & $2(0-25)$ & $2(0-27)^{*}$ & $0.0232^{* * *}$ \\
\hline Hospital mortality, n (\%) & $37(61.6 \%)$ & $39(82.9 \%)$ & $0.02^{* *}$ \\
\hline APACHE II score, median (range) & $21(7-39)$ & $30(15-47)$ & $0.0001^{*}$ \\
\hline SOFA score, median (range) & $11(4-20)$ & $7(2-22)$ & $0.0003^{*}$ \\
\hline SAPS II score, median (range) & $47(20-77)$ & $60(10-110)$ & $0.0014^{*}$ \\
\hline
\end{tabular}

S: Organic dysfunction-free sepsis subgroup. SS: septic shock subgroup. The values are presented as medians and ranges with standard deviation (SD). The following tests were used: *: Student test; **: chi squared test; ***: Mann Whitney test. 
C allele was considered variant for the investigated SNPs. The G allele was dominant in the control group and it was considered to be the wild-type allele. Accordingly, the genotypes found were: variant heterozygotes (GC) or homozygotes (CC) genotypes and wild-type homozygotes GG. Distribution of genotypes in the control group and in the sepsis group, as well as in both septic subgroups was in HardyWeinberg Equilibrium (HWE) for both studied SNPs. (Table 2 and Table 3 )

\section{IL-6 circulating levels}

Patients with septic shock had significantly higher plasmatic IL-6 levels (median 132.9 pg/ $\mathrm{mL}$, range $22.23-10240 \mathrm{pg} / \mathrm{mL}$ ), compared to the organ dysfunction-free subgroup (median $54.9 \mathrm{pg} / \mathrm{mL}$, range 13.2-6566 $\mathrm{pg} / \mathrm{mL})(\mathrm{OR}=$ $2.57,95 \% \mathrm{CI}=1.98-6.74, p=0.0012)$.

\section{Distribution of the IL-6 -174 G/C Polymorphism}

There were no statistically significant differences between septic patients and the healthy control group $(\mathrm{p}=0.56)$. In the whole septic study group, $87.9 \%$ of patients had the variant genotype for IL-6 -174 G/C polymorphism, which was similar to the control group (90.6\%) (all data shown in Table 2). Although the IL-6 -174 GG genotype was more frequent in the septic group (43\%) than in the control group (38.5\%), the difference was not significant and none of the variant genotypes or allele was associated with sepsis, compared to the controls (Table 4). Likewise, no significant association with sepsis risk was found in septic patients with variant heterozygous (GC) or homozygous (CC) genotypes, compared to the GG genotype (Table 2).

Table 2. Genotypes distribution of IL-6 gene polymorphisms in septic and control groups

\begin{tabular}{lllll}
\hline $\begin{array}{l}\text { Gene poly- } \\
\text { morphism }\end{array}$ & $\begin{array}{l}\text { Genotype or } \\
\text { allele }\end{array}$ & $\begin{array}{l}\text { Study group } \\
\mathbf{n = 1 0 7} \mathbf{( 5 2 . 7 \%} \%\end{array}$ & $\begin{array}{l}\text { Control group } \\
\mathbf{n = 9 6} \mathbf{( 4 7 . 3 \% )}\end{array}$ & $\begin{array}{l}\text { p } \\
\text { OR (95\% CI) }\end{array}$ \\
\hline IL-6 -174 G/C & GG & $46(43.0)$ & $37(38.5)$ & Reference \\
\cline { 2 - 5 } & GC & $48(44.9)$ & $50(52.1)$ & $0.38,0.77(0.42-1.39)$ \\
\cline { 2 - 5 } & CC & $13(12.1)$ & $9(9.4)$ & $0.75,1.16(0.44-3.01)$ \\
\cline { 2 - 5 } & GC+CC & $61(57.0)$ & $59(61.5)$ & $0.52,0.83(0.47-1.45)$ \\
\cline { 2 - 5 } & Allele G & $140(65.4)$ & $124(64.5)$ & Reference \\
\cline { 2 - 5 } IL-6 -572 G/C & Gllele C & $74(34.6)$ & $68(35.4)$ & $0.85,0.96(0.64-1.45)$ \\
\cline { 2 - 5 } & GG & $82(76.6)$ & $79(82.3)$ & Reference \\
\cline { 2 - 5 } & GC & $23(21.5)$ & $16(16.7)$ & $0.36,1.38(0.68-2.81)$ \\
\cline { 2 - 5 } & GC+CC & $25(1.9)$ & $17(1.0)$ & $0.98,1.92(0.17-21.7)$ \\
\cline { 2 - 5 } & Allele G & $187(87.4)$ & $174(90.6)$ & Reference \\
\cline { 2 - 5 } & Allele C & $27(12.6)$ & $18(9.4)$ & $0.29,1.39(0.74-2.62)$ \\
\hline
\end{tabular}

Note: OR: Odds Ratio; CI: Confidence Interval. Distribution of genotypes in the control group and in the sepsis group, was in Hardy-Weinberg Equilibrium (HWE) for both studied SNPs ( $p>0.05)$. GG: wildtype homozygous genotype, GC: heterozygous genotype, CC: variant homozygous genotype, $G C+C C$ : represent patients with variant genotype (both heterozygous and homozygous) 
Table 3. Genotype and allele frequencies of IL-6 -174 G/C and -572G/C gene polymorphisms in septic patients subgroups and according to outcome.

\begin{tabular}{|c|c|c|c|c|c|c|}
\hline $\begin{array}{l}\text { Genotype } \\
\text { or allele }\end{array}$ & $\begin{array}{l}\text { SS } \\
(n=47) \\
(43.9 \%)\end{array}$ & $\begin{array}{l}S \\
(n=60) \\
(56.1 \%)\end{array}$ & $\begin{array}{l}P^{a} \\
\text { OR }(95 \% \text { CI })\end{array}$ & $\begin{array}{l}\text { Deceased } \\
(n=76) \\
(71.1 \%)\end{array}$ & $\begin{array}{l}\text { Survi- } \\
\text { vors } \\
(n=31) \\
(28.9 \%)\end{array}$ & $\begin{array}{l}P^{b} \\
\text { OR }(95 \% \text { CI })\end{array}$ \\
\hline $\begin{array}{l}\text { IL-6 } \\
-174 \mathrm{GG}\end{array}$ & $20(42.6)$ & $26(43.3)$ & Reference & $\begin{array}{c}33 \\
(43.4)\end{array}$ & $\begin{array}{c}13 \\
(41.9)\end{array}$ & Reference \\
\hline $\begin{array}{l}\text { IL-6 } \\
-174 \mathrm{GC}\end{array}$ & $23(48.9)$ & $25(41.7)$ & $\begin{array}{c}0.66 \\
1.19(0.53-2.69)\end{array}$ & $\begin{array}{c}35 \\
(46.1)\end{array}$ & $\begin{array}{c}13 \\
(41.9)\end{array}$ & $\begin{array}{c}0.89 \\
1.06(0.43-2.62)\end{array}$ \\
\hline $\begin{array}{l}\text { IL-6 } \\
-174 \mathrm{CC}\end{array}$ & $\begin{array}{c}4 \\
(8.5) \\
\end{array}$ & $\begin{array}{c}9 \\
(15.0) \\
\end{array}$ & $\begin{array}{c}0.53 \\
0.57(0.15-2.15)\end{array}$ & $\begin{array}{c}8 \\
(10.5) \\
\end{array}$ & $\begin{array}{c}5 \\
(16.1) \\
\end{array}$ & $\begin{array}{c}0.49 \\
0.63(0.17-2.28)\end{array}$ \\
\hline $\begin{array}{l}\text { IL-6 } \\
-174 \mathrm{GC}+\mathrm{CC}\end{array}$ & $\begin{array}{c}27 \\
(57.4)\end{array}$ & $\begin{array}{c}34 \\
(56.7)\end{array}$ & $\begin{array}{c}0.93 \\
1.03(0.47-2.23)\end{array}$ & $\begin{array}{c}43 \\
(56.5)\end{array}$ & $\begin{array}{c}18 \\
(50.1)\end{array}$ & $\begin{array}{c}0.88 \\
0.94(0.40-2.19)\end{array}$ \\
\hline $\begin{array}{l}\text { IL-6 } \\
-174 \mathrm{G}\end{array}$ & $63(67.1)$ & $77(64.2)$ & Reference & $\begin{array}{c}101 \\
(66.4)\end{array}$ & $\begin{array}{c}39 \\
(62.9)\end{array}$ & Reference \\
\hline $\begin{array}{l}\text { IL-6 } \\
-174 \mathrm{C}\end{array}$ & $31(23.9)$ & $43(35.8)$ & $\begin{array}{c}0.66 \\
0.88(0.49-1.55)\end{array}$ & $\begin{array}{c}51 \\
(33.6)\end{array}$ & $\begin{array}{c}23 \\
(37.1)\end{array}$ & $\begin{array}{c}0.62 \\
0.85(0.46-1.58)\end{array}$ \\
\hline $\begin{array}{l}\mathrm{IL}-6 \\
-572 \mathrm{GG}\end{array}$ & $42(89.4)$ & $40(66.7)$ & Reference & $\begin{array}{c}59 \\
(77.6) \\
\end{array}$ & $\begin{array}{c}23 \\
(74.2) \\
\end{array}$ & Reference \\
\hline $\begin{array}{l}\text { IL-6 } \\
-572 \mathrm{GC}\end{array}$ & $\begin{array}{c}5 \\
(10.6) \\
\end{array}$ & $18(30.0)$ & $\begin{array}{c}0.01 \\
0.26(0.08-0.78)\end{array}$ & $\begin{array}{c}15 \\
(19.7) \\
\end{array}$ & $\begin{array}{c}8 \\
(25.8) \\
\end{array}$ & $\begin{array}{c}0.53 \\
0.73(0.27-1.95)\end{array}$ \\
\hline $\begin{array}{l}\text { IL-6 } \\
-572 \mathrm{CC}\end{array}$ & $\begin{array}{c}0 \\
(0.0)\end{array}$ & $\begin{array}{c}2 \\
(3.3)\end{array}$ & $\begin{array}{c}0.49 \\
0.19(0.008-4.09)\end{array}$ & $\begin{array}{c}2 \\
(2.6)\end{array}$ & $\begin{array}{c}0 \\
(0.0)\end{array}$ & $\begin{array}{c}0.37 \\
1.97(0.09-42.73)\end{array}$ \\
\hline $\begin{array}{l}\text { IL-6 } \\
-572 \mathrm{GC}+\mathrm{CC}\end{array}$ & $\begin{array}{c}5 \\
(10.6) \\
\end{array}$ & $\begin{array}{c}20 \\
(33.3) \\
\end{array}$ & $\begin{array}{c}0.006 \\
0.23(0.08-0.69)\end{array}$ & $\begin{array}{c}17 \\
(22.3) \\
\end{array}$ & $\begin{array}{c}8 \\
(25.8) \\
\end{array}$ & $\begin{array}{c}0.70 \\
0.82(0.31-2.18)\end{array}$ \\
\hline $\begin{array}{l}\text { IL-6 } \\
-572 \mathrm{G}\end{array}$ & $89(94.7)$ & $98(81.6)$ & Reference & $\begin{array}{c}133 \\
(87.5)\end{array}$ & $\begin{array}{c}54 \\
(87.1)\end{array}$ & Reference \\
\hline $\begin{array}{l}\text { IL-6 } \\
-572 \mathrm{C}\end{array}$ & $5(5.3)$ & $22(18.4)$ & $\begin{array}{c}0.004 \\
0.25(0.09-0.69)\end{array}$ & $\begin{array}{c}19 \\
(12.5)\end{array}$ & $\begin{array}{c}8 \\
(12.9)\end{array}$ & $\begin{array}{c}0.93 \\
0.96(0.39-2.33)\end{array}$ \\
\hline
\end{tabular}

SS: Septic shock subgroup; S: organ dysfunction free-sepsis subgroup; pa: $p$ values for individual genotypes organ dysfunction free-sepsis subgroup vs. septic shock subgroup; pb: $p$ values for deceased group vs. survivors group. Distribution of genotypes in the groups, was in Hardy-Weinberg Equilibrium (HWE) for both studied SNPS $(p>0.05)$.

Further analysis revealed no differences among the patient subgroups regarding the IL-6 $-174 \mathrm{G} / \mathrm{C}$ GC heterozygous genotype distribution $(\mathrm{p}=0.54)$ (all the data shown in Table 2). However, a higher, almost double percentage of
IL-6 -174 G/C CC homozygotes was present in the organ dysfunction-free sepsis group, which might point to a possible protective role of this genotype in the development of severe sepsis, but the difference had no statistical significance, 
Table 4. Model 1: Logistic regression analysis of IL-6 genotypes SNP and allele frequency in sepsis compared to controls. Model 2: Logistic regression analysis of IL-6 genotypes SNP and allele frequency in septic shock patients compared to organ dysfunction-free sepsis patients.

\begin{tabular}{|c|c|c|c|c|c|}
\hline & & Variable & OR & $95 \%$ CI & $\mathbf{p}$ \\
\hline \multirow{10}{*}{$\begin{array}{l}\text { - } \\
\overline{0} \\
\text { o } \\
\Sigma\end{array}$} & \multirow{5}{*}{$\begin{array}{l}\mathrm{IL}-6 \\
-174 \mathrm{G} / \mathrm{C}\end{array}$} & GG & 1.20 & $0.69-2.11$ & 0.52 \\
\hline & & $\mathrm{GC}$ & 0.75 & $0.43-1.30$ & 0.30 \\
\hline & & $\mathrm{CC}$ & 1.34 & $0.54-3.28$ & 0.53 \\
\hline & & Allele $\mathrm{G}$ & 0.75 & $0.30-1.84$ & 0.53 \\
\hline & & Allele C & 0.83 & $0.47-1.46$ & 0.52 \\
\hline & \multirow{5}{*}{$\begin{array}{l}\text { IL-6 } \\
-572 \mathrm{G} / \mathrm{C}\end{array}$} & GG & 0.71 & $0.35-1.40$ & 0.32 \\
\hline & & GC & 1.37 & $0.67-2.78$ & 0.38 \\
\hline & & $\mathrm{CC}$ & 1.81 & $0.16-20.28$ & 0.63 \\
\hline & & Allele $\mathrm{G}$ & 0.55 & $0.05-6.20$ & 0.63 \\
\hline & & Allele C & 1.42 & $0.71-2.82$ & 0.32 \\
\hline \multirow{10}{*}{$\frac{N}{\frac{N}{0}}$} & \multirow{5}{*}{$\begin{array}{l}\text { IL-6 } \\
-174 \mathrm{G} / \mathrm{C}\end{array}$} & GG & 0.97 & $0.45-2.10$ & 0.94 \\
\hline & & $\mathrm{GC}$ & 1.34 & $0.62-2.90$ & 0.45 \\
\hline & & $\mathrm{CC}$ & 0.53 & $0.15-1.83$ & 0.38 \\
\hline & & Allele $\mathrm{G}$ & 1.90 & $0.55-6.60$ & 0.31 \\
\hline & & Allele C & 1.03 & $0.48-2.23$ & 0.94 \\
\hline & \multirow{5}{*}{$\begin{array}{l}\text { IL-6 } \\
-572 \mathrm{G} / \mathrm{C}\end{array}$} & GG & 4.20 & $1.44-12.27$ & 0.008 \\
\hline & & $\mathrm{GC}$ & 0.28 & $0.09-0.82$ & 0.02 \\
\hline & & $\mathrm{CC}$ & 0.00 & $0.00-0.00$ & 0.99 \\
\hline & & Allela_G & 0.00 & $0.00-0.00$ & 0.99 \\
\hline & & Allele C & 0.24 & $0.08-0.70$ & 0.008 \\
\hline
\end{tabular}

OR: Odds Ratio; CI: Confidence Interval

nor was it significant in the $\mathrm{GC}+\mathrm{CC}$ genotype group compared to the GG genotype septic patients (Table 3). Moreover, we found no statistically significant difference in the septic shock development risk for $\mathrm{C}$ versus $\mathrm{G}$ allele ( $\mathrm{p}$ $=0.66)$ (Table 3).

Evaluation of a possible association between genotypes and mortality seemed to have a similar trend, CC genotype being more common in survivors compared to the deceased $(16.1 \%$ vs. $10.5 \%$ ), although overall differences were beyond statistical significance $(\mathrm{p}=0.49)$ (Table 3).

\section{Distribution of the IL-6-572 G/C Polymorphism}

Regarding the IL-6 -572 G/C SNP, no association was observed between its genotypes and sepsis predisposition, even if heterozygotes $\mathrm{GC}$ and homozygotes $\mathrm{CC}$ were more frequent in the septic study group $(21.5 \%$ and $1.9 \%)$ compared to controls (16.7\% and $1.0 \%$, respectively); similarly, no statistically significant difference between the study and control groups was observed in case of the $\mathrm{C}$ allele $(12.6 \%$ vs. $9.4 \%$ ), (Table 2); this lack of association was supported by logistic regression analysis of IL-6 gene polymorphisms genotypes and allele 
frequencies between the two groups (Table 4). Compared to $\mathrm{GG}$, the $\mathrm{CC}$ or $\mathrm{GC}+\mathrm{CC}$ genotypes were associated with a significantly different sepsis risk (septic shock and organ dysfunctionfree sepsis subgroups) (Table 3).

Genotype and allele frequencies in the two septic subgroups for this SNP are listed in Table 3. Their comparison reveals that GG had a higher frequency in the septic shock subgroup (89.4\%) compared with the organ dysfunction-free sepsis subgroup (66.7\%), whereas heterozygous GC genotype occurred more frequently in the ODfree septic subgroup $(30.0 \%$ vs. $10.6 \%)$ ( $p$ $=0.01)$; the variant IL- $6 \mathrm{GC}+\mathrm{CC}$ genotypes were statistically significant more frequent in the less severe septic group $(p=0.006)$ (Table $3)$; likewise, the $\mathrm{C}$ allele of this polymorphism was statistically significant re frequent in this subgroup compared to the normal $\mathrm{G}$ allele (OR $=0.25 ; 95 \% \mathrm{CI}=0.09-0.69, p=0.004$ ) (Table 3) and patients carrying it were associated with the OD-free septic group (OR $=0.24 ; 95 \% \mathrm{CI}$ $=0.08-0.70, p=0.008$ ) (Table 4). The findings strongly suggest a protective role of this allele in the development of some severe forms of sepsis. However, they were not supported by genotype and allele distribution according to outcome, since there was no association of the $\mathrm{C}$ allele with mortality (Table 3).

\section{Interrelation between IL-6 levels - IL-6 SNPS}

Since patients with septic shock had significantly higher circulating IL-6 levels compared to organ dysfunction-free sepsis patients, we analyzed the possible role of the studied polymorphisms in their occurrence. No significant association between the genotypes of the studied IL-6 polymorphisms and their plasma levels was found in septic patients. Therefore, patients with homozygous GG genotype of the $-174 \mathrm{G} / \mathrm{C}$ SNP had elevated IL-6 circulating levels but this difference was not statistically significant compared to the other genotypes, either considered separately or together (Table 5). Moreover, logistic regression analysis of the variant genotypes of IL-6 $-174 \mathrm{G} / \mathrm{C}$ or -572 G/C SNPs or the alleles was not associated with significantly modified levels of the circulating cytokine in the septic study group $(p>0.05)$.

Given the differences in serum cytokine levels in the studied subgroups, we investigated the possible association of elevated levels in septic shock patients with the genotypes of the studied polymorphisms. In both polymorphisms, we found a statistically significant difference between subgroups for the GG genotype circulating levels (Table 5).

\section{Discussion}

Several genetic studies have evaluated the implications of cytokine gene involvement in the inflammatory response for the particular course of infection, some demonstrating the role of genetic background in sepsis susceptibility and its different outcomes.

Alteration of cytokine expression, as an intrinsic component of the innate immunity involved in infection, governed in part by gene variants and especially SNPs, has been demonstrated to influence sepsis risk and its mortality (22).

IL-6 cytokine, which has an essential role in triggering and modulating sepsis systemic inflammation by its fast dynamics that increases early circulating levels in infectious injury, is a promising biomarker in sepsis; the role of genetic variation within the regulatory part of its gene has been evaluated in numerous studies on adults and children with systemic infections.

Two biallelic SNPs located in the IL-6 gene promoter at positions -174 and -572 , namely -174 $\mathrm{G} / \mathrm{C}$ (rs1800795) and -572 G/C (rs1800796), have been associated with modifications in sepsis risk and mortality, possibly through 
Table 5. IL-6 circulating levels* and genetic polymorphism

\begin{tabular}{|c|c|c|c|c|c|}
\hline & Genotype & Study group & $\mathbf{S}$ & SS & $\mathbf{p}^{\mathbf{a}}$ \\
\hline \multirow[t]{6}{*}{ IL-6 -174 G/C } & GG & $\begin{array}{c}100.4 \\
(13.27-10235)\end{array}$ & $\begin{array}{c}69.1 \\
(13.27-4066)\end{array}$ & $\begin{array}{c}129.6 \\
(36.20-10240)\end{array}$ & 0.03 \\
\hline & $\mathrm{GC}$ & $\begin{array}{c}87.06 \\
(17.82-6566) \\
\end{array}$ & $\begin{array}{c}69.7 \\
(17.82-6566) \\
\end{array}$ & $\begin{array}{c}126.3 \\
(31.86-3260) \\
\end{array}$ & 0.08 \\
\hline & $\mathrm{CC}$ & $\begin{array}{c}37.08 \\
(18.85-690.6)\end{array}$ & $\begin{array}{c}36.5 \\
(18.8-246.3)\end{array}$ & $\begin{array}{c}136.2 \\
(22.20-690.6)\end{array}$ & 0.51 \\
\hline & $\mathrm{GC}+\mathrm{CC}$ & $\begin{array}{c}81.94 \\
(17.82-6566) \\
\end{array}$ & $\begin{array}{c}48.04 \\
(17.8-6566)\end{array}$ & $\begin{array}{c}136.2 \\
(22.20-3260) \\
\end{array}$ & 0.01 \\
\hline & $\mathrm{p}^{\mathrm{b}}$ & 0.20 & 0.47 & 0.80 & \\
\hline & $\mathrm{p}^{\mathrm{c}}$ & 0.46 & 0.57 & 0.58 & \\
\hline \multirow[t]{6}{*}{ IL-6 -572 G/C } & GG & $\begin{array}{c}93.89 \\
(13.27-10240) \\
\end{array}$ & $\begin{array}{c}48.04 \\
(13.27-4066) \\
\end{array}$ & $\begin{array}{c}132.9 \\
(22.20-10240) \\
\end{array}$ & 0.003 \\
\hline & $\mathrm{GC}$ & $\begin{array}{c}69.16 \\
(24.34-6566) \\
\end{array}$ & $\begin{array}{c}54.9 \\
(24.34-6566) \\
\end{array}$ & $\begin{array}{c}248.7 \\
(97.80-3260) \\
\end{array}$ & 0.09 \\
\hline & $\mathrm{CC}$ & $\begin{array}{c}455.9 \\
(81.94-829.80)\end{array}$ & $\begin{array}{c}455.9 \\
(81.94-829.80)\end{array}$ & NA & - \\
\hline & $\mathrm{GC}+\mathrm{CC}$ & $\begin{array}{c}80.67 \\
(24.34-6566) \\
\end{array}$ & $\begin{array}{c}58.05 \\
(24.3-6566) \\
\end{array}$ & $\begin{array}{c}284.7 \\
(97.8-3260)\end{array}$ & 0.11 \\
\hline & $\mathrm{p}^{\mathrm{b}}$ & 0.67 & 0.45 & 0.52 & \\
\hline & $\mathrm{p}^{\mathrm{c}}$ & 0.83 & 0.61 & 0.53 & \\
\hline
\end{tabular}

*Plasma level (ng/mL), expressed as median (range); pa: $S$ vs. SS; pb: for genotypes, GG vs. GC+CC genotypes, Kruskal-Wallis test; pc: GG vs. CC genotypes, Mann Whitney test. NA: data not available.

OR: Odds Ratio; CI: Confidence Interval

changes in cytokine production and circulating levels $(17,23)$. However, the results of their influence on sepsis predisposition and outcome as well as on plasma IL-6 levels are divergent or even contradictory. Our aim was to evaluate this genetic determinism of the two SNPs in a critically ill septic patient (ICU) cohort.

One of our main findings was that IL-6 -174 G/C and IL-6 -572 G/C were not associated with the risk of sepsis development. We first evaluated the association between variant genotype and allele of rs1800795(IL-6 -174 G/C) and sepsis risk and we could not establish any statistically significant correlation. This conclusion is different from the findings of a recent study, in which the $\mathrm{C}$ allele was revealed to increase pneumonia-induced sepsis risk (24), and also from the results published by many authors who studied this aspect on pediatric cohorts $(12,25,26)$. Most of them indicated that the $G$ allele was predictive for sepsis development: Harding et al. in premature newborns, Ahrens et al. in Gram-positive infections in very low birth weight (VLBW) infants, and recently, in infants with early onset sepsis (EOS) $(12,25$, 26). A pediatric study also showed the $G$ allele to be statistically significant more frequent in infected children compared to controls (10). 
Contradictory findings were revealed by other researchers, underlining that the $\mathrm{C}$ allele of IL-6 -174 G/C polymorphism might increase predisposition to sepsis in children and blood stream infections in infants or even favor fungal infections in certain infant populations (27). There are only few pediatric studies which do not detect any association between IL-6 -174 G/C $(28,29)$ and sepsis; Chauhan's (2008) metaanalysis found a modest association of this SNP with neonatal sepsis risk (30). In adults, most authors invalidated this association in different populations: in severe septic adults, including surgical sepsis $(31,32)$, in patients with chronic nephropathy (17), and in systemic infections of uncertain meningococcal and pneumococcal etiology $(13,33)$. A recent meta-analysis conducted by Gao et al. strongly demonstrated the lack of evidence of a significant association between IL-6 -174 G/C and sepsis risk, this being consistent with our results (8).

On the other hand, we found only three studies on the association between IL-6 -572 G/C polymorphism and sepsis risk, all of them with different findings from ours. One study showed a statistically significant association between the wild-type homozygous genotype and sepsis risk in patients with chronic renal disease, the second revealed only a small difference in genotype frequencies between infected children and controls while the third suggested a lower sepsis risk associated to IL-6 - 572 G/C gene polymorphism variant in certain populations $(10,17,18)$.

The second goal of our study was to assess the association between IL-6 studied polymorphisms and sepsis severity. To this end, the septic patients under study were divided into two subgroups depending on severity, i.e. organ dysfunction-free and septic shock subgroup (4).

For further analysis, patients were divided according to outcome (exitus/survival) during hospitalization. No association was found between IL-6 -174 G/C gene polymorphism and sepsis mortality, and no significant differences in the frequencies of alleles or genotypes between the OD-free subgroup and the septic shock group. A possible explanation for the lack of significance in differences among subgroups may be due to the heterogeneity of the studied group explained by the fact that we included all patients with sepsis/septic shock during the study period.

Although with partly contradictory results, some studies revealed a statistically significant role of this SNP in sepsis outcome. Most studies provided evidence of an unfavorable role of the CC genotype of Il-6 $-174 \mathrm{G} / \mathrm{C}$ on sepsis severity (10), and on GG genotype association with less severe forms of systemic infections and increased survival rates in sepsis $(13,32,34)$.

Homozygous CC genotype involvement of this SNP in haplotype clades that are strongly associated with multiple organ dysfunction syndrome (MODS) and mortality in severe septic patients has also been demonstrated (35). However, some reports point to the association of GG genotype with severe forms and higher mortality in systemic meningococcal infection and in certain infant populations $(25,33)$.

Our results are consistent with recent findings in patients with chronic renal sepsis, and in a group of non-septic severe renal patients, as well as in newborn studies $(17,27,35)$. Lack of IL-6 $-174 \mathrm{G} / \mathrm{C}$ polymorphism association with sepsis mortality is supported by the meta-analysis conducted by Gao et al. on seven studies, with only one positive correlation with the recessive model (CC vs $\mathrm{GC} / \mathrm{GG}$ ), prior to Bonferroni correction (8).

Our main finding in the current study was the association between GC genotype of the IL-6 -572 G/C SNP and septic shock. We also conclude that the $\mathrm{C}$ allele of IL-6 $-572 \mathrm{G} / \mathrm{C}$ 
SNP had a protective role in the development of severe sepsis, in contrast with the results of a pediatric study, which obtained no association of IL-6 -572G/C with sepsis severity (10). The contradictory results may be consequences of the small number of subgroups.

Numerous studies demonstrated an increase in IL-6 circulating levels in the severe forms of sepsis and septic shock, and provided evidence of their association with sepsis mortality (37, 38). In our study, the identification of statistically significant elevated plasma levels of IL-6 in septic shock compared to organ dysfunction-free septic patients was consistent with recent studies supporting its role of potential early prognostic biomarker due to its upregulated levels in sepsis, particularly in septic shock (6).

Our finding regarding the lack of association between variant genotype or allele of IL-6 -174 G/C gene polymorphism and IL-6 plasma levels on the entire group of septic patients supports the results of studies on burn patients with and without sepsis, and polytraumatised patients (35, $39)$. On the other hand, the major role of $G$ allele of IL-6 -174 G/C in promoting the inflammatory response is confirmed in our study by the significant increase of IL-6 circulating levels in patients with septic shock in GG genotype but not in the other two genotypes of IL-6 -174 G/C. This finding is similar to the results of other clinical trials which demonstrate the association of GG genotype with increased circulating levels in sepsis $(11,25)$; a single study indicates that $\mathrm{C}$ allele of IL-6 $-174 \mathrm{G} / \mathrm{C}$ is associated with increased IL-6 levels in infants (23).

On the other hand, the elevated circulating IL-6 levels we obtained in patients with septic shock and GG genotype of IL-6 -572 G/C SNP were similar to Panayides' results in septic patients with chronic nephropathies who developed MODS (17), and are somehow consistent with the reduced transcriptional activity by IL-6 -572 G/C polymorphisms showed by $\mathrm{Gu}$ et al. in a sepsis population (18).

Significant association of GG genotype of IL-6 -572 G/C with septic shock risk and high IL-6 circulating levels could be arguments for a poor outcome in sepsis. However, our results point out the absence of an association of this genotype with mortality; a possible explanation for this finding could be the deaths by other causes rather than infectious within the group, which could lead to an interpretation bias. Absence of this SNP association with infection-related mortality is supported by two other studies on sepsis-associated chronic nephropathy and in a pediatric group $(10,17)$.

To our knowledge, there are very few studies evaluating the role of IL-6 -572 G/C polymorphism in sepsis risk and severity. The three studies in the literature refer to particular patient populations (trauma, chronic renal) or children $(10,17,18)$. Investigation of a population of severe septic patients that is homogeneous as representativeness for the profile of an ICU septic patient by age, source of infection, and Caucasian race, represents the strength of our study. We also emphasize that it advances the new approaches in sepsis definition and reclassification introduced in 2016 (4). We believe that within the context of the most studied IL-6 -174G/C polymorphism, our findings bring additional solid arguments for its lack of association with sepsis risk, severity and mortality. Another strong point of the present study is represented by the fact that two IL-6 SNPs were considered simultaneously.

However, certain limitations of the present study should be mentioned. First, the relatively small number of septic patients and controls under study interferes with the statistical power of the groups; further studies are needed in order to validate these results, especially on IL-6 -174 $\mathrm{G} / \mathrm{C}$ and $-572 \mathrm{G} / \mathrm{C}$ polymorphisms, given the 
paucity of data from other studies as well as the singularity of our results. Secondly, the group is representative of a reduced area for which the clinic provides services (the central region of the country).

\section{Conclusions}

Our study concludes that IL-6 -174 G/C gene polymorphism has no significant contribution to sepsis risk evaluation and management, it underlines the role of IL-6 $-572 \mathrm{G} / \mathrm{C}$ SNP as a possible prognostic marker in sepsis, and it reconfirms the IL- 6 role as a biomarker in severe sepsis patients.

\section{Acknowledgements}

The research has been carried out within the project: The clinical relevance of coding genes polymorphisms cytokines (IL-6, IL-10, TNFalfa) and cellular receptors (CD14, TREM-1, TLR4) and PAI in sepsis, no. 17801/2/2015, funded through internal research grants by the University of Medicine and Pharmacy of Tîrgu Mures, Romania.

\section{Author Disclosure Statement}

The authors report no conflicts of interest.

\section{Abbreviations}

APACHE II = Acute Physiology and Chronic Health Evaluation - II

$\begin{aligned} \text { ARMS }= & \text { Amplification-refractory } \\ & \text { mutation system }\end{aligned}$

CI = Confidence interval

DNA $=$ Deoxyribonucleic acid

EDTA $=$ Ethylenediaminotetraacestic acid

EGDT = Early Goal Directed Therapy

$\begin{array}{ll}\mathrm{EOS} & =\text { Early onset sepsis } \\ \mathrm{HWE} & =\text { Hardy-Weinberg equilibrium } \\ \mathrm{ICU} & =\text { Intensive care unit } \\ \mathrm{IL} & =\text { Interleukin } \\ \text { MODS } & \text { Multiple organ dysfunction } \\ & \text { syndrome } \\ \text { OD } & =\text { Organ dysfunction } \\ \text { OR } & =\text { Odds ratio } \\ \text { PAMPs } & \text { Pathogen-associated molecular } \\ & \text { patterns } \\ \text { PCR } & \text { Polymerase chain reaction } \\ \text { PRRs } & =\text { Pattern recognition receptors } \\ \text { RFLP } & =\text { Restriction fragment length } \\ & \text { polymorphism } \\ \text { SAPS II }= & \text { Simplified Acute Physiology } \\ & \text { Score }- \text { II } \\ \text { SD } & =\text { Standard deviation } \\ \text { SNP } & =\text { Single nucleotide } \\ & \text { polymorphism } \\ \text { SOFA } & =\text { Sequential Organ Failure } \\ & \text { Assessment } \\ \text { SPSS } & =\text { Statistical Package for Social } \\ & \text { Sciences } \\ \text { VLBW } & \text { Very low birth weight } \\ & \end{array}$

\section{References}

1. Mariansdatter SE, Eiset AH, Søgaard KK, Christiansen CF. Differences in reported sepsis incidence according to study design: a literature review. BMC Med Res Methodol. 2016 Oct;16(1)137. DOI 10.1186/s12874016-0237-9. DOI: 10.1186/s12874-016-0237-9

2. Rivers E, Nguyen B, Havstad S, Ressler J, Muzzin A, Knoblich B, et al. Early goal-directed therapy in the treatment of severe sepsis and septic shock. N Engl J Med. 2001 Nov;345(19):1368-77. DOI: 10.1056/ NEJMoa010307

3. Wira CR, Dodge K, Sather J, Dziura J. Meta-analysis of protocolized goal-directed hemodynamic optimization for the management of severe sepsis and septic shock in the emergency department. West J Emerg Med. 2014 Feb;15(1):51-9. DOI: 10.5811/westjem.2013.7.6828 
4. Singer M, Deutschman CS, Seymour CW, Shankar-Hari M, Annane D, Bauer M, et al. The Third International Consensus Definitions for sepsis and septic shock. JAMA. 2016 Feb;315(8):801-10. DOI: 10.1001/ jama.2016.0287

5. Georgescu AM, Szederjesi J, Dobreanu M, Copotoiu SM, Voidăzan S, Huțanu A, et al. Soluble urokinase-type plasminogen activator receptor (suPAR) - a possible biomarker for bacteremia in sepsis. Rev Romana Med Lab. 2015 Mar;23(1):59-73. DOI: 10.1515/rrlm-20150002

6. Feng M, Sun T, Zhao Y, Zhang H. Detection of serum interleukin-6/10/18 levels in sepsis and its clinical significance. J Clin Lab Anal. 2016 May 17; DOI:10.1002/ jcla.21977. DOI: $10.1002 /$ jcla.21977

7. Petilla V, Hynninen M, Takkunen O, Kuusela P, Valtonen M. Predictive value of procalcitonin and interleukin 6 in critically ill patients with suspected sepsis. Intensive Care Med. 2002 Sep;28(9):1220-5. DOI: $10.1007 / \mathrm{s} 00134-002-1416-1$

8. Gao JW, Zhang AQ, Pan W, Yue CI, Zeng L, Gu W, et al. Association between IL-6-174G/C polymorphism and the risk of sepsis and mortality: a systematic review and meta-analysis. PLoS ONE. 2015 Mar;10(3):e0118843. DOI: 10.1371.

9. Skibsted S, Bhasin MK, Aird WC, Shapiro NI. Benchto-bedside review: future novel diagnostics for sepsis - a systems biology approach. Crit Care. 2013 Oct;17(5):231; DOI:10.1186/cc12693. DOI: 10.1186/ cc 12693

10. Michalek J, Svetlikova P, Fedora M, Klimovic M, Klapacova L, Bartosova D, et al. Interleukin-6 gene variants and the risk of sepsis development in children. Hum Immunol. 2007 Sep;68(9):756-60. DOI: 10.1016/j.humimm.2007.06.003

11. Bennermo M, Held C, Stemme S, Ericsson CG, Silveira A, Green F, et al. Genetic predisposition of the interleukin- 6 response to inflammation: implications for a variety of major diseases? Clin Chem. 2004 Nov;50(11):2136-40. DOI: 10.1373/ clinchem.2004.037531

12. Ahrens P, Kattner E, Kohler B, Hartel C, Seidenberg J, Segerer J, et al. Mutations of genes involved in the innate immune system as predictors of sepsis in very low birth weight infants. Pediatr Res. 2004 Apr;55(4):6526. DOI: 10.1203/01.PDR.0000112100.61253.85
13. Martin-Loeches I, Sole-Violan J, Rodriguez de Castro F, Isabel Garcia-Laorden M, Borderias L, Blanquer J, et al. Variants at the promoter of the interleukin- 6 gene are associated with severity and outcome of pneumococcal community-acquired pneumonia. Intensive Care Med. 2012 Feb;38(2):256-62. DOI: 10.1007/s00134-0112406-y

14. Sole-Violan J, Rodriguez de Castro F, Isabel GarciaLaorden M, Blanquer J, Aspa J, Borderias L, et al. Genetic variability in the severity and outcome of community-acquired pneumonia. Respir Med. 2010 Mar;104(3):440-7. DOI: 10.1016/j.rmed.2009.10.009

15. Davis SM, Clark EAS, Nelson LT, Silver RM. The association of innate immune response gene polymorphisms and puerperal group A streptococcal sepsis. Am J Obstet Gynecol. 2010 Mar;202(3):308.e1-8; DOI: 10.1016/j.ajog.2010.01.006. DOI: 10.1016/j. ajog.2010.01.006

16. Jabandziev P, Smerek M, Michalek J, Fedora M, Kosinova L, Hubacek JA, et al. Multiple gene-to-gene interactions in children with sepsis: a combination of five gene variants predicts outcome of life-threatening sepsis. Crit Care. 2014 Jan;18(1):R1; DOI:10.1186/ cc13174. DOI: $10.1186 / \mathrm{cc} 13174$

17. Panayides A, Ioakeimidou A, Karamouzos V, Antonakos N, Koutelidakis I, Giannikopoulos G, et al. -572 G/C single nucleotide polymorphism of interleukin- 6 and sepsis predisposition in chronic renal disease. Eur J Clin Microbiol Infect Dis. 2015 Dec;34(12):2439-46. DOI: $10.1007 / \mathrm{s} 10096-015-2500-0$

18. Gu W, Du DY, Huang J, Zhang LY, Liu Q, Zhu PF, et al. Identification of interleukin-6 promoter polymorphisms in the Chinese Han population and their functional significance. Crit Care Med. 2008 May;36(5):1437-43. DOI: $10.1097 /$ CCM.0b013e31816a0adb

19. Dellinger RH, Levy MM, Rhodes A, Annane D, Gerlach H, Opal SM, et al. Surviving Sepsis Campaign: International guidelines for management of severe sepsis and septic shock: 2012. Crit Care Med 2013. Feb;41(2):580-637.

20. Zhang D, Zhou Y, Wu L, Wang S, Zheng H, Yu B, et al. Association of IL-6 gene polymorphisms with cachexia susceptibility and survival time of patients with pancreatic cancer.Ann Clin Lab Sci. 2008 Spring;38(2):113-119 
21. Daneshmandi S, Pourfathollah AA, Pourpak Z, Heidarnazhad H, Kalvanagh PA. Cytokine gene polymorphism and asthma susceptibility, progress and control level. Mol Biol Rep. 2012 Feb;39(2):1845-53. DOI: $10.1007 / \mathrm{s} 11033-011-0927-7$

22. Namath A, Patterson AJ. Genetic polymorphisms in sepsis. Crit Care Clin. 2009 Dec;25(4): 835-56. DOI: 10.1016/j.ccc.2009.06.004

23. Kilpinen S, Hulkkonen J, Wang XY, Hurme M. The promoter polymorphism of the interleukin- 6 gene regulates interleukin-6 production in neonates but not in adults. Eur Cytokine Netw. 2001 Mar;12(1):62-8.

24. Mao ZR, Zhang SL, Feng B. Association of IL-10 (-819T/C, -592A/C and -1082A/G) and IL-6 -174G/C gene polymorphism and the risk of pneumonia-induced sepsis. Biomarkers. 2016 Jul;7:1-21. DOI: 10.1080/1354750X.2016.1210677

25. Allam G, Alsulaimani AA, Alzaharani AK, Nasr A. Neonatal infections in Saudi Arabia: association with cytokine gene polymorphisms. Centr Eur J Immunol. 2015;40(1)68-77. DOI: 10.5114/ceji.2015.50836

26. Harding D, Dhamrait S, Millar A, Humphries S, Marlow N, Whitelaw A, et al. Is interleukin-6 -174 genotype associated with the development of septicaemia in preterm infants? Pediatrics. 2003 Oct;112(4):800-3. DOI: $10.1542 /$ peds. 112.4 .800

27. Baier RJ, Loggins J, Yanamandra K. IL-10, IL-6 and CD14 polymorphisms and sepsis outcome in ventilated very low birth weight infants. BMC Medicine. 2006 April;4:10; DOI: 10.1186/1741-7015-4-10. DOI: 10.1186/1741-7015-4-10

28. Treszl A, Kocsis I, Szathmari M, Schuler A, Heninger E, Tulassay T, et al. Genetic variants of TNF-alpha, IL-1beta, IL-4 receptor alpha-chain, IL-6 and IL-10 genes are not risk factors for sepsis in low-birth-weight infants. Biol Neonate. 2003 May;83:241-5. DOI: $10.1159 / 000069484$

29. Gopel W, Hartel C, Ahrens P, Konig I, Kattner E, Kuhls E, et al. Interleukin-6 -174-genotype, sepsis and cerebral injury in very low birth weight infants. Genes Immun. 2006 Jan;7(1):65-8. DOI: 10.1038/sj.gene.6364264

30. Chauhan M, McGuireW. Interleukin-6 (-174C) polymorphism and the risk of sepsis in very low birth weight infants: meta-analysis. Arch Dis Child Fetal Neonatal Ed. 2008 Nov;93(6): F427-9. DOI: 10.1136/ adc. 2007.134205
31. Carregaro F, Carta A, Cordeiro JA, Lobo SM, Silva EH, Leopoldino AM. Polymorphisms IL10-819 and TLR-2 are potentially associated with sepsis in brazilian patients. Mem Inst Oswaldo Cruz. 2010 Aug;105(5):64956. DOI: 10.1590/S0074-02762010000500008

32. Schlüter B, Raufhake C, Erren M, Schotte H, Kipp F, Rust S, et al. Effect of the interleukin-6 promoter polymorphism $(-174 \mathrm{G} / \mathrm{C})$ on the incidence and outcome of sepsis. Crit Care Med. 2002 Jan;30(1):32-7. DOI: 10.1097/00003246-200201000-00005

33. Balding J, Healy CM, Livingstone WJ, White B, Mynett-Johnson L, Cafferkey M, et al. Genomic polymorphic profiles in an Irish population with meningococcaemia: is it possible to predict severity and outcome of disease? Genes Immun. 2003 Dec;4(8):533-40. DOI: $10.1038 /$ sj.gene. 6364020

34. Schaaf B, Rupp J, Müller-Steinhardt M, Kruse J, Boehmke F, Maass M, et al. The interleukin-6 -174 promoter polymorphism is associated with extrapulmonary bacterial dissemination in Streptococcus pneumoniae infection. Cytokine. 2005 Aug 21;31(4):324-8. DOI: $10.1016 /$ j.cyto.2005.05.008

35. Sutherland AM, Walley KR, Manocha S, Russell JA. The association of interleukin 6 haplotype clades with mortality in critically ill adults. Arch Intern Med. 2005 Jan;165(1):75-82. DOI: 10.1001/archinte.165.1.75

36. Jeremic V, Alempijevic T, Mijatovic S, Sijacki A, Dragasevic S, Pavlovic S, et al. Clinical relevance of IL-6 gene polymorphism in severly injured patients. Bosn J Basic Med Sci. 2014 May;14(2):110-7.

37. Hack CE, De Groot ER, Felt-Bersma RJ, Nuijens JH, Strack Van Schijndel RJ, Eerenberg-Belmer AJ, et al. Increased plasma levels of interleukin-6 in sepsis. Blood. 1989 Oct;74(5):1704-10.

38. Pallás Beneyto LA, Rodríguez Luis O, Saiz Sánchez C, Cotell Simón O, Bautista Rentero D, Miguel Bayarri V. Prognostic value of interleukin 6 for death of patients with sepsis. Med Clin (Barc). 2016 Oct;147(7):281-6. DOI: 10.1016/j.medcli.2016.06.001

39. Accardo Palumbo A, Forte GI, Pileri D, Vaccarino L, Conte F, D'Ámelio L, et al. Analysis of IL-6, IL-10 and IL-17 genetic polymorphisms as risk factors for sepsis development in burned patients. Burns. 2012 Mar;38(2):208-13. DOI: 10.1016/j.burns.2011.07.022 